\title{
塔里木、四川及鄂尔多斯盆地白云岩储层孔隙成因 探讨及对储层预测的指导意义
}

\author{
赵文智 ${ }^{(1 *}$ ，沈安江 ${ }^{(2)(3)}$, 郑剑锋 ${ }^{(2)(3)}$, 乔占峰 ${ }^{(2)}$ ，王小芳 ${ }^{(2)(3)}$, 陆俊明 (2) (3) \\ (1) 中国石油勘探与生产分公司，北京 100007; \\ (2) 中国石油勘探开发研究院, 北京 100083; \\ (3) 中国石油集团碳酸盐岩储层重点实验室, 杭州 310023 \\ *E-mail: zwz@petrochina.com.cn
}

收稿日期: 2013-07-21; 接受日期: 2013-11-28; 网络版发表日期: 2014-07-31

国家重大科技专项项目 (编号: 2011ZX05004-02)资助

\begin{abstract}
摘要以塔里木、四川和鄂尔多斯盆地蒸发潮坪白云岩储层、蒸发台地白云岩储层、埋藏 白云岩储层和热液白云岩储层为例, 系统阐述了白云岩储层储集空间的成因, 指出原岩(石 灰岩)特征和各种溶蚀作用主导白云岩储层储集空间的发育, 并不是传统观点所认为的白云 石化是重要的孔隙建造作用。蒸发潮坪白云岩储层的孔隙形成于表生期大气淡水对膏云岩 中石膏及未云化灰质的溶蚀; 蒸发台地白云岩储层的孔隙形成于表生期大气淡水对石膏及 未云化文石或高镁方解石颗粒的溶蚀; 埋藏白云岩储层的孔隙主要是对原岩孔隙的继承和 调整，埋藏溶蚀作用对孔隙建造有一定的贡献; 热液白云岩储层晶间孔可能形成于热液白云 石化作用或是对原岩孔隙的继承和调整，晶间溶孔和溶洞形成于热液溶蚀作用. 白云岩的分 布与白云岩储层的分布不完全吻合, 白云石化作用总能形成白云岩, 但不一定是白云岩储 层. 蒸发潮坪白云岩储层侧向上分布于蒸发潮坪亳云岩带, 带状或准层状分布, 受相带控制, 垂向上分布于向上变浅的蒸发潮坪旋回顶部(层序界面之下)的膏云岩中, 多套叠置. 蒸发台 地白云岩储层侧向上分布于蒸发台地(盐湖)周缘及膏盐层之下, 环带状及层状分布, 受相带 控制，垂向上分布于向上变浅旋回顶部(层序界面之下)的礁滩相白云岩、毫云岩中, 多套叠 置. 埋藏白云岩储层侧向上分布于台缘或台内白云石化(交代或重结晶)的多孔礁滩相沉积 中, 受相带控制, 垂向上分布于向上变浅旋回顶部(层序界面之下)的晶粒白云岩中, 多套叠 置. 热液白云岩储层沿断裂、不整合面等热液通道呈准层状、透镜状分布.
\end{abstract}

\section{1 白云岩储层概述}

\section{1 白云岩储层的重要性}

白云岩储层是非常重要的油气储层. 据全球 226
个大中型及以上碳酸盐岩油气田(占全球碳酸盐岩油 气储量的 90\%)的统计(表 1)(白国平, 2006), 下古生界 及三叠系碳酸盐岩油气田几乎全为白云岩储层, 上 古生界碳酸盐岩油气田白云岩储层和灰岩储层的比

\footnotetext{
中文引用格式: 赵文智, 沈安江, 郑剑锋, 等. 2014. 塔里木、四川及鄂尔多斯盆地白云岩储层孔隙成因探讨及对储层预测的指导意义. 中国科学: 地球科学, 44: 1925-1939

英文引用格式: Zhao W Z, Shen A J, Zheng J F, et al. 2014. The porosity origin of dolostone reservoirs in the Tarim, Sichuan and Ordos basins and its implication to reservoir prediction. Science China: Earth Sciences, doi: 10.1007/s11430-014-4920-6
} 
表 1 地质历史时期全球碳酸盐岩油气田白云岩储层与灰岩储层比率

\begin{tabular}{|c|c|c|c|c|c|}
\hline \multirow{2}{*}{ 序号 } & \multirow{2}{*}{ 地层 } & \multicolumn{2}{|c|}{ 油气田数量(个) } & \multirow{2}{*}{ 白云岩储层比率 $(\%)(102$ 个) } & \multirow{2}{*}{ 灰岩储层比率(\%)(124 个) } \\
\hline & & 油田 & 气田 & & \\
\hline 1 & 第三系 & 36 & 10 & 20 & 80 \\
\hline 2 & 白严系 & 58 & 8 & 17 & 83 \\
\hline 3 & 侏罗系 & 18 & 4 & 77 & 23 \\
\hline 4 & 三叠系 & 4 & 2 & 100 & 0 \\
\hline 5 & 二叠系 & 13 & 6 & 74 & 26 \\
\hline 6 & 石炭系 & 16 & 11 & 56 & 44 \\
\hline 7 & 泥盆系 & 15 & 4 & 47 & 53 \\
\hline 8 & 志留系 & 2 & 1 & 100 & 0 \\
\hline 9 & 奥陶系-上前寒武系 & 12 & 6 & 100 & 0 \\
\hline
\end{tabular}

率相当, 白严系和第三系则以灰岩储层为主. 白云岩 储层的发育似乎与三叠纪干旱的气候背景有关, 同 时还与地质年代有关, 年代越古老的碳酸盐岩层系, 白云岩储层的比率越高.

四川盆地碳酸盐岩气田 $90 \%$ 以上的天然气储量 富集于白云岩储层中, 主要有震旦系灯影组藻白云 岩储层(施泽进等, 2010; 方少仙等, 2003), 石炭系黄 龙组、二叠系长兴组及三叠系飞仙关组(王一刚和文 应初, 1996; 黄先平和杨雨, 2003)礁滩白云岩储层(残 留部分原岩结构或完全重结晶), 雷口坡组和嘉陵江 组与蒸发环境相关的亳云岩储层及礁丘白云岩储层 (沈安江等, 2008), 近期在川中高石梯-磨溪地区震旦 系灯影组和寒武系龙王庙组白云岩勘探取得突破, 展示了良好的天然气勘探前景. 鄂尔多斯盆地唯一 的碳酸盐岩油气田靖边气田的储层为马家沟组马五 1 4 白云岩风化壳储层(何江等, 2009; 乔琳等, 2007), 近期在白云岩风化壳之下马五 5 10 的天然气勘探取 得突破, 为粉细晶白云岩储层. 华北任丘油田的储层 为潜山白云岩储层, 实际上是不同类型的白云岩储 层被抬升剥蚀和受表生岩溶作用再改造的产物. 塔 里木盆地寒武系及中下奥陶统蓬莱坝组、鹰山组白云 岩储层发育(赵文智等, 2011, 2012), 潜山区已发现了 以英买 32 井及山 1 井为代表的潜山油气藏, 内幕区 白云岩储层发育, 勘探潜力大. 所以, 塔里木、四川 和鄂尔多斯盆地白云岩勘探前景良好, 应加强白云 岩及白云岩储层成因和分布规律研究.

\section{2 白云岩成因概述}

正因为白云岩储层重要的油气勘探价值, 白云 岩成因一直是多年来的研究热点, 并提出了很多白
云石化模式. 主流的白云石化模式有以下 8 种：渗透 回流白云石化(Adams 和 Rhodes, 1961)、毛细管浓缩 白云石化(Bush, 1973)、蒸发洜白云石化(Mckenzie 等, 1980)、混合水白云石化(Badiozamani，1973)、调整压实白云石化(Hardie, 1987; Montanez, 1994)、埋藏压实白云石化(Mattes 和 Mountjoy，1980)、海水热对 流白云石化(Vahrenkamp 和 Swart, 1994)和构造热液 白云石化(Graham 等, 2006).

不管有多少种白云石化模式，白云石化作用不 外乎发生于两大阶段.一是同生阶段, 二是埋藏阶段. 同生阶段的白云石化作用主要与干旱气候背景下的 蒸发沉积环境相关, 高镁方解石和文石溶蚀释放的 $\mathrm{Mg}^{2+}$ 为白云石化作用提供了镁离子来源, 形成的白 云岩往往保留原岩结构, 包括颗粒白云岩及泥晶白 云岩, 白云石晶体以泥粉晶级为主(图 1(a)和(b)). 埋 藏阶段的白云石化作用主要与不同埋藏深度的富镁 成岩介质有关, 镁离子的来源很复杂, 可以是富镁矿 物及粘土矿物转换时释放的镁离子, 也可以是封存 海水中富集的镁离子及来自深源流体的镁离子，浅 埋藏成岩流体有调整-压实排挤流和有机酸-压实排 挤流, 深埋藏成岩流体主要有埋藏热卤水和热液, 形 成的白云岩往往为细晶级以上的晶粒白云岩(图 1(c) 和(d)), 而且随着埋藏深度的加大和作用时间的加长, 晶体粒度往往变大，可残留部分原岩结构.

\section{3 白云岩孔隙成因概述}

关于白云石化作用在孔隙建造和破坏中的作用, 长期以来都是争论的焦点(Fairbridge，1957; Moore, 1989; Lucia, 1999).

由于储集空间主要发育于各类白云岩中，即使 

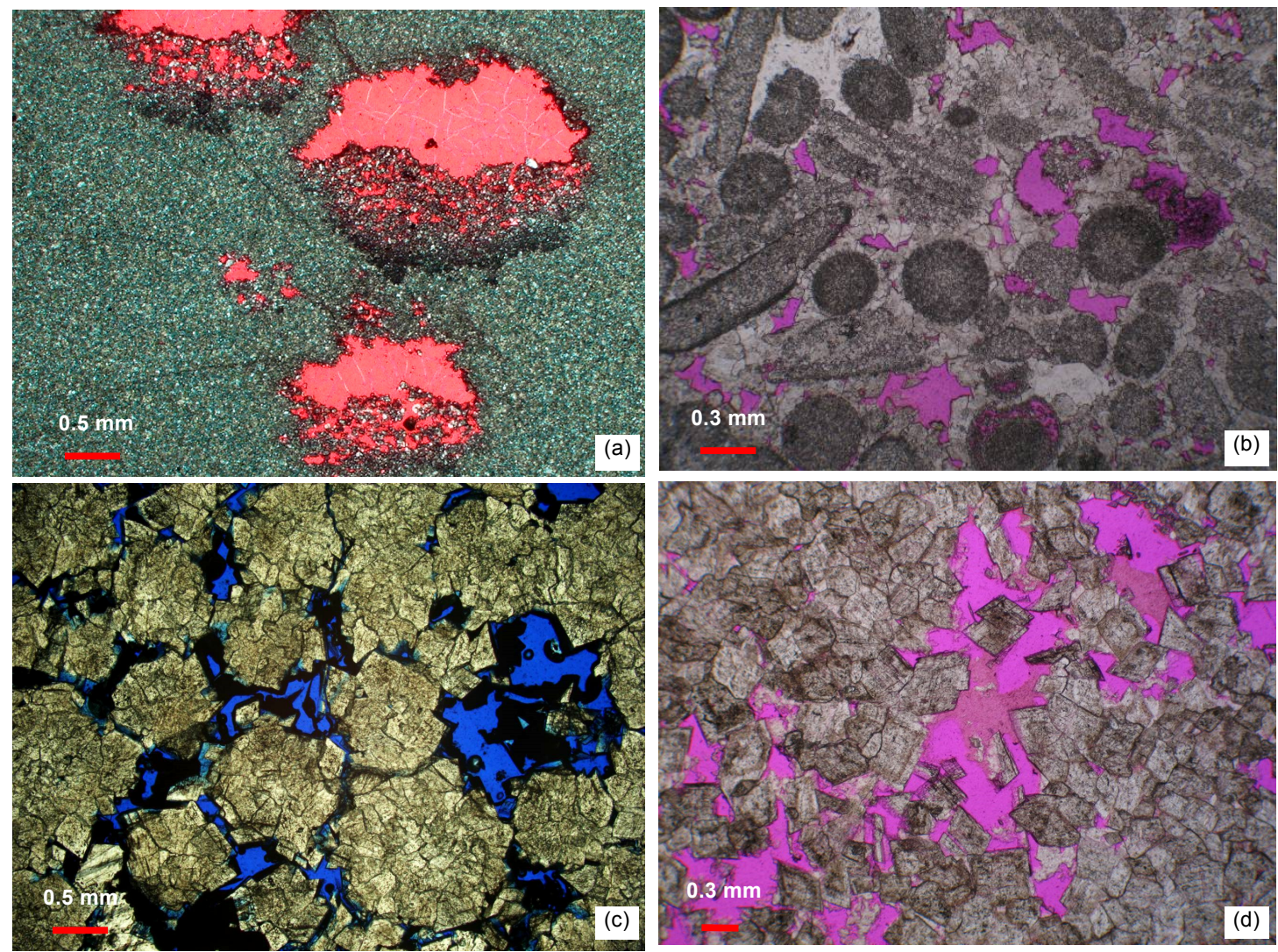

图 1 同生阶段和埋藏阶段形成的白云岩显微特征

(a) 含膏泥晶白云岩, 石膏结核及斑块发生溶解形成膏模孔，膏模孔下部被粉晶白云石部分充填，铸体片，单偏光，下奥陶统马家沟组五段， 鄂尔多斯盆地, 陕 133 井第 3 筒芯; (b) 颗粒白云岩, 颗粒成分有鲕粒及内碎屑等, 由泥粉晶白云石构成, 䲡粒铸模孔和残留粒间孔发育, 铸 体片, 单偏光, 中寒武统, 塔里木盆地牙哈地区, 牙哈 7X-1 井, $5833.00 \mathrm{~m}$; (c) 鲕粒白云岩, 鲕粒 $0.6 ~ 0.8 \mathrm{~mm}$, 由较暗的粉-细晶白云石组成, 粒间孔发育, 胶结物不发育, 沥青充填程度较高, 蓝色铸体片, 单偏光, 下三叠统飞仙关组, 四川盆地, 罗家 2 井, $3243.97 \mathrm{~m}$; (d) 细中晶白云

岩, 白云石为半自形-自形晶, 晶间(溶)孔发育, 铸体片, 单偏光, 上寒武统, 塔里木盆地英买力地区, 英买 33 井, $5519.75 \mathrm{~m}$

是礁滩储层，储集空间也主要发育于白云石化的礁 滩相沉积中, 如四川盆地环开江-梁平海槽二叠系长 兴组生物礁储层(雷市军和强子同, 1994). Beach (1982)所做的研究工作揭示巴哈马台地上新统-更新 统碳酸盐沉积物经历白云石化之后孔隙度大大增加. 因此，白云石化对孔隙的建造作用被提上了非常重 要的地位.

Wey1(1960)根据质量守恒原理, 研究了白云石 化过程中通过方解石的溶蚀提供 $\mathrm{CO}_{3}{ }^{2-}$ 的局限来源, 并形成大量与白云石化作用相关孔隙的案例. 另外, 他注意到如果白云石化完全是分子对分子的交代, 碳酸盐的来源也很局限, 那么, 方解石向较大比重的 白云石转化时，会导致孔隙度增加 $13 \%$.

然而, Lucia等(1994)指出: “分子对分子交代的白
云石化理论不适用于博内尔岛上新统-更新统的碳酸 盐岩. 事实上，目前还没有证据可以证实白云石化理 论适用于所有碳酸盐岩的孔隙形成机理. 白云岩孔 隙度值总是等于或小于其原岩的值，这表明原岩(石 灰岩)的特征可能是白云石化过程中影响孔隙变化的 重要因素”.

Purser 等(1994)则持较为折中的观点. 他们认为 原岩(石灰岩)特征对白云岩最终孔隙度的影响固然 很重要, 但 $\mathrm{CO}_{3}{ }^{2-}$ 来源局限的成岩环境也很重要, 只 有在这种成岩环境下，白云石化作用才能导致孔隙 度的增加.

与白云石化作用相关的孔隙丧失在埋藏成岩环 境下是非常常见的, 尤其是通过封堵孔隙的鞍状白云 石胶结物的沉淀导致孔隙丧失(Moore, 1989; Moore 和 
Heydari, 1993).

\section{2 白云岩储层孔隙成因实例解剖}

塔里木、四川和鄂尔多斯盆地发育四种成因的白 云岩，分别为蒸发潮坪白云岩、蒸发台地白云岩、埋 藏白云岩和热液白云岩(表 2)(赵文智等, 2012). 本文 将在前人对上述三个盆地白云岩成因认识的基础上,
重点剖析白云岩储集空间的成因，进一步揭示白云 石化作用在白云岩储层孔隙建造中的作用.

\section{1 蒸发潮坪白云岩储层}

蒸发潮坪白云岩形成于干旱气候条件下的蒸发 潮坪环境, 被认为是毛细管浓缩白云石化和蒸发洜 白云石化作用的产物 (图 2)(赵文智等, 2012; 郑剑锋 等, 2010). 以塔里木盆地中下寒武统为例，阐述蒸发

表 2 塔里木、四川和鄂尔多斯盆地白云岩类型

\begin{tabular}{|c|c|c|c|c|}
\hline 序号 & 白云岩类型 & 白云岩特征 & 白云岩成因 & 实例 \\
\hline 1 & 蒸发潮坪白云岩 & $\begin{array}{l}\text { 泥粉晶白云岩、(含膏)泥粉晶 } \\
\text { 白云岩 }\end{array}$ & $\begin{array}{l}\text { 毛细管浓缩白云石化; } \\
\text { 蒸发葲白云石化 }\end{array}$ & $\begin{array}{l}\text { 1) 塔里木盆地中下寒武统 } \\
\text { 2) 四川盆地嘉陵江组和雷口坡组 }\end{array}$ \\
\hline 2 & 蒸发台地白云岩 & $\begin{array}{l}\text { 颗粒白云岩、礁丘白云岩, 保 } \\
\text { 留原岩结构; 泥粉晶白云岩、 } \\
\text { (含膏)泥粉晶白云岩 }\end{array}$ & 渗透回流白云石化 & $\begin{array}{l}\text { 1) 塔里木盆地中下寒武统 } \\
\text { 2) 四川盆地黄龙组、飞仙关组、嘉陵江组 } \\
\text { 和雷口坡组 } \\
\text { 3) 鄂尔多斯盆地马家沟组 }\end{array}$ \\
\hline 3 & 埋藏白云岩 & $\begin{array}{l}\text { 以结晶白云岩为主, 包括细 } \\
\text { 晶、中晶和粗晶白云岩, 可能 } \\
\text { 残留部分原岩结构 }\end{array}$ & $\begin{array}{l}\text { 调整-压实白云石化; 埋 } \\
\text { 藏-压实白云石化; 海水 } \\
\text { 热对流白云石化 }\end{array}$ & $\begin{array}{l}\text { 1) 塔里木盆地上寒武统及下奥陶统蓬莱 } \\
\text { 坝组 } \\
\text { 2) 四川盆地龙王庙组、黄龙组、长兴组 } \\
\text { 3) 鄂尔多斯盆地马家沟组四段 }\end{array}$ \\
\hline 4 & 热液白云岩 & $\begin{array}{l}\text { 以粗晶、极粗晶白云石和鞍状 } \\
\text { 白云石为特征, 充填各类孔 } \\
\text { 洞和裂缝 }\end{array}$ & 构造热液白云石化 & 塔里木盆地塔中下奥陶统鹰山组 \\
\hline
\end{tabular}

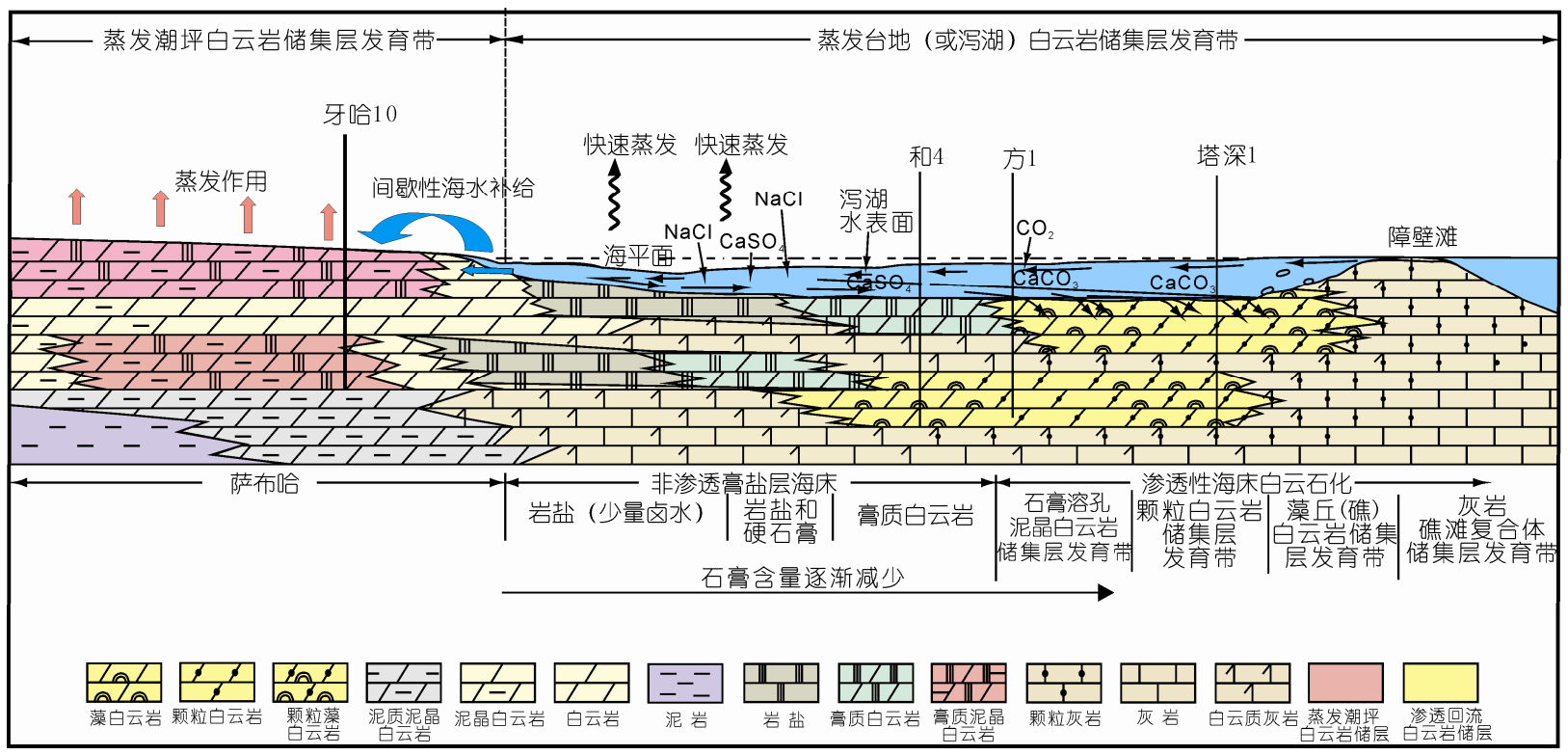

图 2 蒸发沉积环境白云石化模式图

该图展示了同生阶段与干旱气候背景下蒸发沉积环境相关的白云石化作用(包括萨布哈地层序列的毛细管浓缩白云石化和蒸发洜白云石化 及蒸发台地的渗透回流白云石化)及由此导致的不同岩性单元的侧向和垂向上的变化, 潮间-潮上坪膏云岩, 台内含膏泥晶白云岩、颗粒白 云岩及礁(丘)白云岩均可发育成有效储层. 据赵文智等(2011) 
潮坪白云岩储层储集空间的成因.

塔里木盆地岩芯和薄片所见最典型的蒸发潮坪 白云岩储层见于牙哈 10 井第 4 筒芯 6210.10 6213.20 $\mathrm{m}$ 井段(图 3), 位于萨布哈向上变浅序列的中上部, 储层的载体为一套含石膏的潮间-潮上坪泥晶白云岩 (图 4(a)), 石膏含量由下向上逐渐增多, 直至变为亳 岩层, 石膏的溶蚀作用由上向下逐渐减弱, 直至未见 石膏溶解的膏云岩. 中下部以致密泥晶白云岩为特 征, 几乎不含石膏斑块或结核. 上部以含石膏斑块或 结核的膏云岩为特征, 石膏溶解形成膏模孔, 孔隙度 5\% 10\%, 由下至上孔隙度逐渐增加, 反映越靠近暴 露面, 石膏的溶解程度越强, 渗透率为 $0.1 \sim 100 \mathrm{md}$, 高渗透率与裂缝有关. 顶部为石膏层溶解导致白云 岩层垮塌形成的角砾白云岩, 砾间孔和砾间缝发育, 孔隙度约 5\%, 但渗透率可达 $100 \mathrm{md}$.

在萨布哈向上变浅的地层序列中, 石膏主要分 布于中上部, 中下部以泥晶白云岩为主, 中上部的石 膏有两种产状, 中部以斑块状或结核状石膏散布于 泥晶白云岩中为特征, 形成亳云岩, 上部以亳岩层和 膏云岩或泥晶白云岩互层为特征, 由下至上构成气 候逐渐干旱和石膏含量逐渐增多的序列.

石膏结核(或斑块)及膏岩层的沉淀非常重要, 为 石膏的溶解和膏溶孔的形成奠定了物质基础, 而蒸 发潮坪环境的过渡属性又为频繁的大气淡水溶蚀作 用提供了地质背景. 这就很好地解释了蒸发潮坪白
云岩储层为什么主要发育于萨布哈地层序列的中上 部，而中下部的纯泥晶白云岩反而不能发育成有效 储层的原因(图 5). 事实上, 塔里木盆地中下寒武统 泥晶白云岩非常发育, 但不含石膏的泥晶白云岩往 往很致密, 石膏为膏溶孔的发育奠定了物质基础. 蒸 发潮坪白云岩储层的孔隙成因决定膏云岩如远离大 气淡水溶蚀面(层序界面或暴露面)或暴露于表生环 境的时间不够长，也不能发育成有效储层.

蒸发潮坪白云岩储层还广泛发育于四川盆地嘉 陵江组和雷口坡组(图 4(b))、鄂尔多斯盆地马家沟组 (图 1(a)), 岩性均以泥粉晶白云岩、含膏泥粉晶白云 岩为主, 垂向上往往与膏盐层互层, 构成多个向上变 浅的旋回. 储层发育的主控因素为：1) 干旱气候条 件下的蒸发潮坪为毛细管浓缩白云石化和蒸发原白 云石化提供了地质背景；2）蒸发潮坪石膏的沉淀为 储层的发育奠定了物质基础；3）同生期大气淡水溶 蚀作用使石膏溶解形成膏模孔及膏岩层溶解导致白 云岩垮塌形成砾间孔缝.

干旱气候条件下 $\mathrm{Ca}^{2+}$ 和 $\mathrm{CO}_{3}{ }^{2-}$ 来源局限的成岩环 境导致胶结物缺乏, 白云石化作用早于大气淡水对 石膏的溶蚀作用，不易溶的白云石构成孔隙支撑格 架, 这些均有利于孔隙的保存. 模拟实验揭示在表生 成岩环境, 白云岩在 $\mathrm{CO}_{2}$ 水溶液中几乎是不溶解的, 灰岩的溶解速率远大于白云岩, 石膏则快速溶解, 这 证实了白云石化作用早于大气淡水对石膏及灰质的

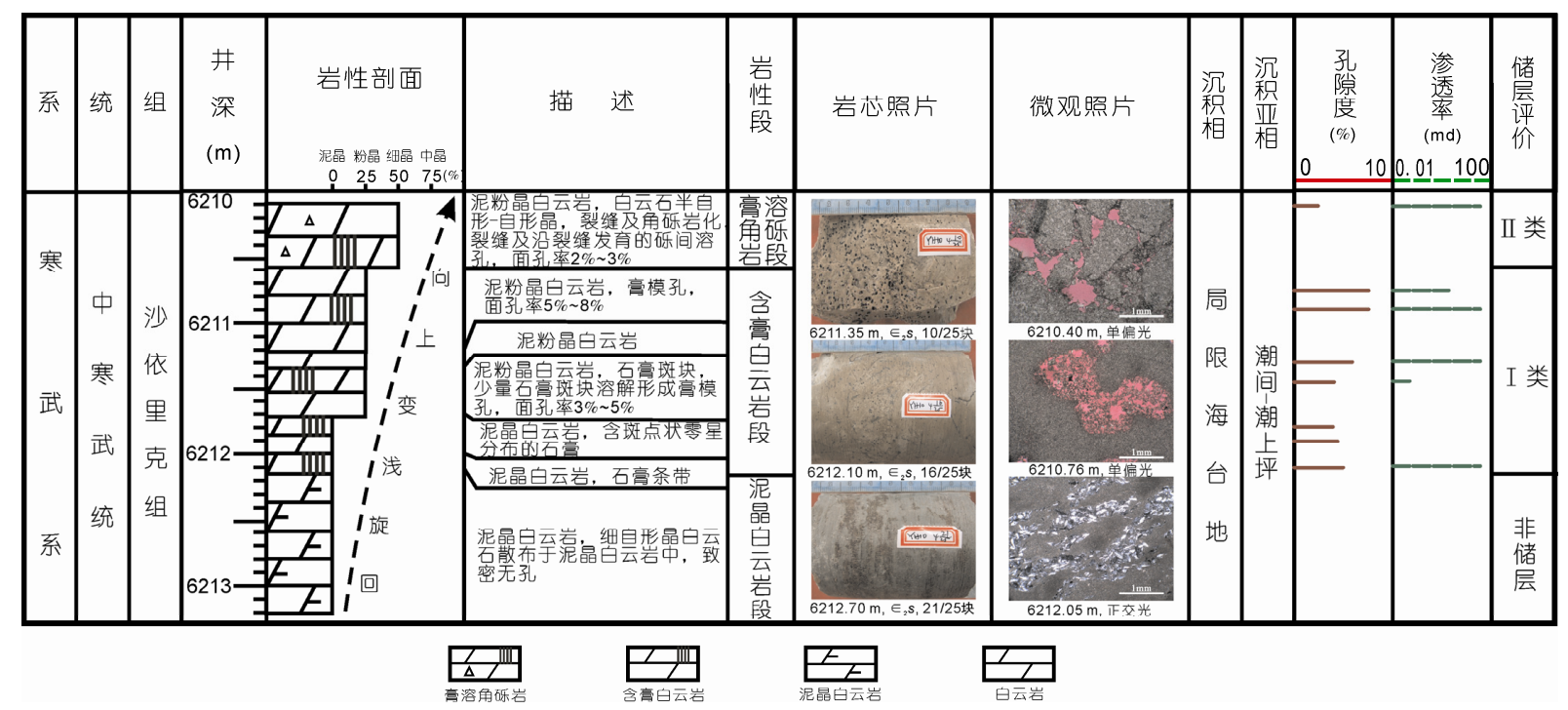

图 3 牙哈 10 井第 4 筒芯蒸发潮坪白云岩沉积-成岩作用及孔隙成因综合柱状图 

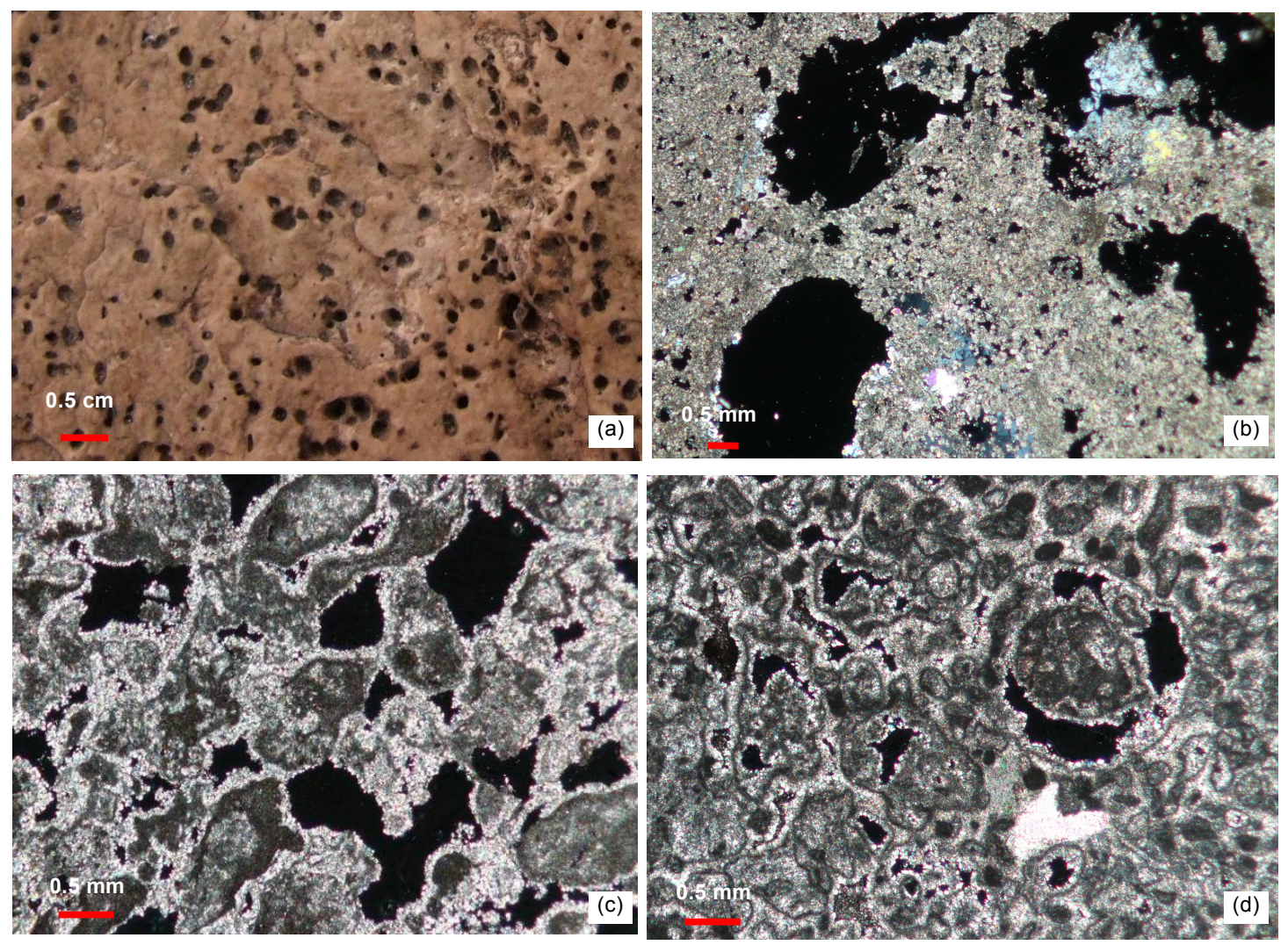

图 4 蒸发潮坪白云岩储层和蒸发台地白云岩储层显微特征

(a) 黄灰色膏质泥晶云岩, 蜂窝状或米粒状的膏模孔发育, 新鲜面上见石亳半充填, 岩芯, 寒武系, 塔里木盆地牙哈地区, 牙哈 10 井, 4-10/25; (b) 含硬石膏泥晶白云岩, 硬石膏结核或晶粒溶解形成膏模孔或晶模孔, 晶模孔大小 $0.1 ~ 0.2 \mathrm{~mm}$, 溶模孔大小一般在 $1 \mathrm{~cm}$ 左右, 未充填, 正 交光, 中三叠统雷口坡组一段, 四川盆地磨溪地区, 磨 28 井, $2802.17 \mathrm{~m}$; (c) 亮晶藻团块白云岩, 藻团块为亮晶白云石半胶结, 残留粒间孔发 育, 面孔率 15\%, 正交光, 中三叠统雷口坡组三段, 四川盆地川西北地区, 中坝 80 井, $3134.02 \mathrm{~m}$; (d) 亮晶藻团块白云岩, 藻团块 $0.4 ~ 1 \mathrm{~mm}$ 不 等, 形态不规则, 具藻粘结现象, 粒间孔及扩溶孔为亮晶白云石半胶结, 残余孔隙面孔率 $9 \%$, 正交光, 中三叠统雷口坡组三段, 四川盆地川 西北地区, 中坝 80 井, $3133.36 \mathrm{~m}$

溶蚀作用(范明等, 2007).

\section{2 蒸发台地白云岩储层}

蒸发台地白云岩形成于干旱气候条件下的蒸发 台地(或瀉湖/盐湖)环境, 被认为是渗透回流白云石 化作用的产物 (图 2)(赵文智等, 2012; 郑剑锋等, 2010), 气候持续干旱可以导致台缘带的礁滩发生渗 透回流白云石化. 以四川盆地雷口坡组三段为例, 阐 述蒸发台地白云岩储层储集空间的成因.

四川盆地雷口坡组三段颗粒白云岩和藻丘白云 岩是在干旱气候背景下的障壁蒸发瀉湖环境发育的 一套蒸发台地白云岩储层, 主要分布在台地边缘和 台内颗粒浅滩微相, 呈带状或准层状大面积分布, 原 岩为颗粒结构的碳酸盐岩, 并与膏岩层互层, 具有非
常重要的勘探价值. 以中坝气田中 46 井为例, 该井 储层单层厚度 1 3 $\mathrm{m}$, 累计厚度超过 $100 \mathrm{~m}$ (图 6), 垂 向上呈多次旋回, 岩性主要为砾屑白云岩、砂屑白云 岩、藻粘结格架白云岩和鲕粒白云岩(图 4(c)和(d)), 少量稁云岩.

储集空间以残余粒间孔、藻丘格架孔及颗粒铸模 孔为主, 石膏主要充填于粒间孔和格架孔中, 铸模孔 不见石膏充填, 这说明渗透回流白云石化作用早于 同生期大气淡水溶蚀作用, 渗透回流白云石化过程 中沉淀的石膏充填于粒间孔和格架孔中, 随后的大 气淡水溶蚀作用导致未云化的文石质颗粒及石膏溶 解形成铸模孔和石膏溶孔. 储层物性主要表现为中 孔-中渗、中孔-高渗特征, 孔隙度最高可达 $25 \%$, 渗 透率达 $131 \times 10^{-3} \mu \mathrm{m}^{2}$, 属中孔-中渗和中孔-高渗孔隙 

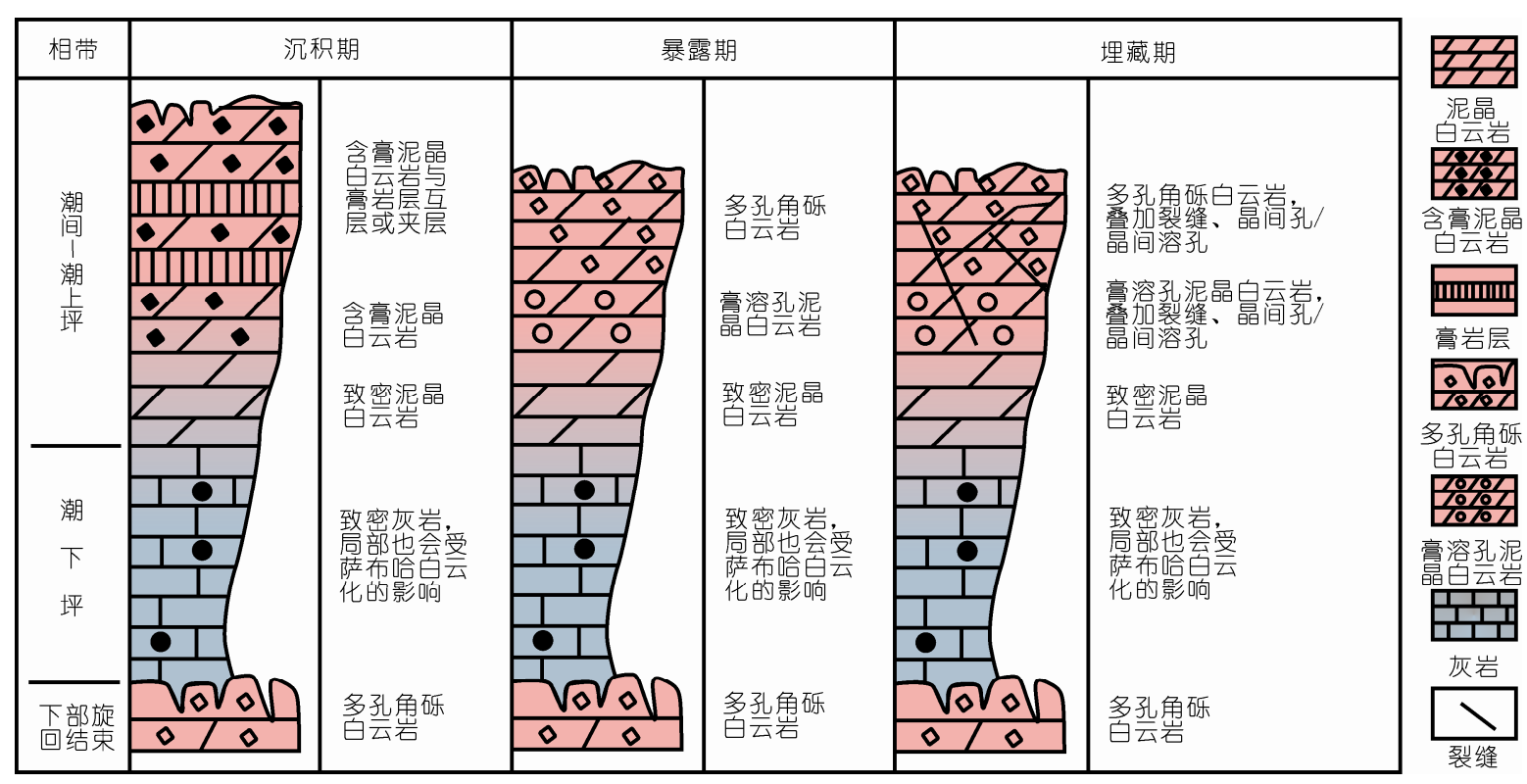

图 5 塔里木盆地中下寒武统蒸发潮坪白云岩储层发育模式图

有效储层发育于萨布哈向上变浅旋回的上部, 受层序界面(或暴露面)、及沉积相带共同控制, 孔隙形成于膏云岩中石膏的溶解及膏岩层溶解 导致的白云岩层垮塌和多孔角砾白云岩的形成. 据赵文智等(2012)

型储层.

渗透回流白云石化作用可导致台内或台缘礁滩 (丘)发生组构选择性白云石化, 保留原岩结构, 但孔 隙主要由两部分构成, 一是原生的残余粒间孔和格 架孔，二是次生的颗粒铸模孔和膏溶孔，而上覆蒸发 岩常常形成盖层. 储层发育于干旱气候背景, 又经常 受大气淡水溶蚀作用的改造, 往往位于高频旋回或 三级旋回向上变浅序列的上部, 侧向上与膏岩层相 变, 垂向上为膏岩层覆盖.

侧向上，蒸发台地(或瀉湖)由陆向障壁方向，蒸 发盐沉积逐渐减少, 向陆一侧可以是成层的膏岩层, 而向海一侧则变为斑块状石亳散布于沉积物中. 垂 向上, 随着气候的进一步干旱, 膏岩层将向海一侧迁 移，逐渐覆盖于下伏各类白云岩之上. 这就导致了蒸 发台地(或瀉湖)靠陆一侧, 膏岩层下伏的碳酸盐岩往 往未发生白云石化或弱白云石化, 而瀉湖靠海一侧, 膏岩层下伏的多孔碳酸盐岩往往发生渗透回流白云 石化(图 2), 经随后的大气淡水溶蚀作用后, 被侧向 迁移的膏岩层覆盖, 通常所说的盐下白云岩储层主 要赋存于这类储盖组合中.

蒸发台地白云岩储层还广泛发育于塔里木盆地 中下寒武统(图 1(b)和 7(a)), 四川盆地黄龙组(图 7(b))、飞仙关组(图 1(c))、嘉陵江组和鄂尔多斯盆地 马家沟组四段. 岩性以台缘及台内礁滩相沉积白云 石化形成的颗粒白云岩、礁(丘)白云岩为主, 滩间海 泥晶灰岩白云石化可以形成泥粉晶白云岩和粉细晶白 云岩, 白云岩、灰岩和膏盐层(甚至是盐岩层)在垂向上 和侧向上均可发生相互交替, 构成多个向上变浅的旋 回. 储层发育的主控因素为: 1) 干旱气候条件下的蒸 发台地为渗透回流白云石化提供了地质背景; 2) 多孔 高能礁滩相沉积及渗透回流白云石化过程中沉淀的石 膏为蒸发台地白云岩储层的发育提供了物质基础; 3) 同生期大气淡水溶蚀是孔隙形成的关键, 尤其是未云 化的文石质颗粒、灰泥和石膏的组构选择性溶解.

同理, 干旱气候条件下 $\mathrm{Ca}^{2+}$ 和 $\mathrm{CO}_{3}{ }^{2-}$ 来源局限的 成岩环境导致胶结物缺乏, 白云石化作用早于大气 淡水对未云化的文石质颗粒、灰泥和石膏的溶蚀作用, 不易溶的白云石构成孔隙支撑格架，这些均有利于 孔隙的保存.

\section{3 埋藏白云岩储层}

埋藏白云岩储层形成于埋藏成岩环境，被认为 是埋藏白云石化作用的产物(赵文智等, 2012; 郑剑 锋等, 2010), 包括浅埋藏成岩环境的调整-压实白云 
图 6 中坝 46 井雷三段 1-26 筒芯蒸发台地白云岩沉积-成岩作用及孔隙成因综合柱状图

石化作用、深埋藏成岩环境的埋藏-压实白云石化作 用. 以塔里木盆地上寒武统-中下奥陶统鹰山组为例, 阐述埋藏白云岩储层储集空间的成因.

塔里木盆地埋藏白云岩比较发育, 层位上主要 见于上寒武统丘里塔格组和下奥陶统蓬莱坝组, 平
面上主要见于塔西台地、罗西台地及塘南台缘带礁滩 和台内礁滩. 在观察研究的 60 余口井中, 有超过 90\%的井均见埋藏白云岩.

埋藏白云岩在塔里木盆地发育与分布的基本特 点是：1）埋藏早期交代白云石呈零星状散布于灰岩 

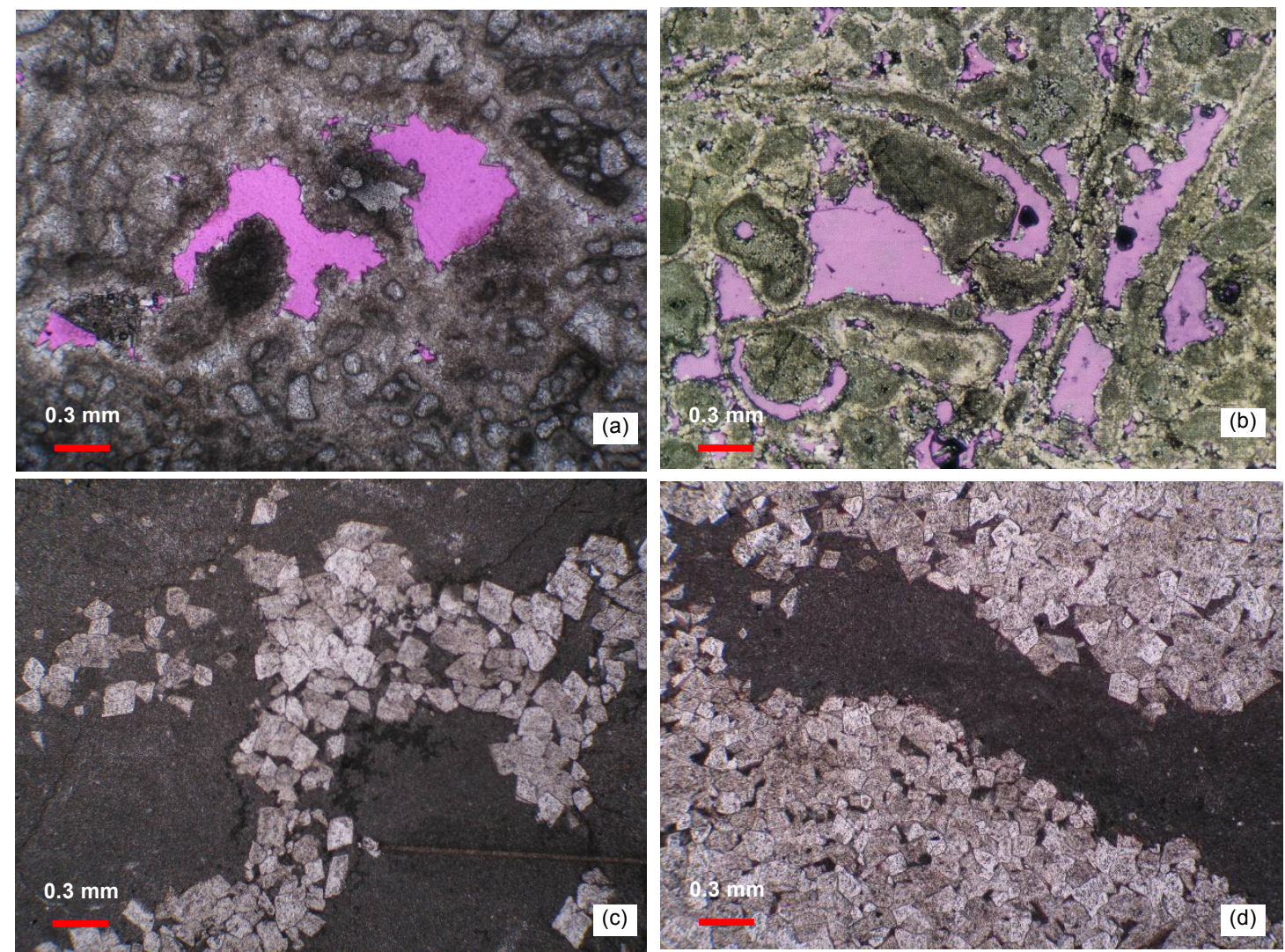

图 7 蒸发台地白云岩储层和埋藏白云岩显微特征

（a）藻礁白云岩, 原岩为藻礁灰岩, 原岩结构保留, 胶结物具世代结构: 一世代为纤状或刃状, 二世代为粒状, 成份均为白云石, 残留格架孔 经历了溶蚀扩大, 单偏光, 铸体片, 下寒武统, 塔里木盆地塔中-巴楚地区, 方 1 井, $4600.50 \mathrm{~m}$; (b) 亮晶砂屑生屑白云岩, 保留原岩结构, 粒 间孔、体腔孔及生屑壳的铸模孔, 以腹足类、瓣鳃类为主, 形成于陆表海蒸发潮坪、潮间环境, 铸体片, 单偏光, 石炭系黄龙组, 四川开江七 里峡, 七里 8 井, $4996.30 \mathrm{~m}$; (c) 泥晶灰岩, 沿缝合线发生白云石化, 细晶白云石自形晶呈零星状散布于灰泥中, 缝合线为埋藏白云石化提供 了介质通道, 单偏光, 中下奥陶统鹰山组, 塔里木盆地塔北地区, 轮古 9 井, $5741.72 \mathrm{~m}$; (d) 泥晶灰岩, 沿缝合线发生白云石化, 细晶白云石自 形晶呈零星状散布于灰泥中, 缝合线为埋藏白云石化提供了介质通道, 当白云石化持续进行时, 可形成白云岩, 残留未云 化的灰泥, 单偏光, 中下奥陶统鹰山组, 塔里木盆地塔北地区, 轮古 42 井, $5897.70 \mathrm{~m}$

中，白云石化程度不高，其中，具泥晶结构的灰岩比 颗粒结构的灰岩更易发生白云石化(图 7(c)), 随着埋 藏深度和持续时间的加大, 白云石逐渐富集, 由沿着 缝合线呈斑块状分布至连续层状分布(图 7(d)), 这样 一个较为完整的序列在塔里木盆地塔中、塔北地区从 鹰山组至蓬莱坝组能清晰可见；2) 埋藏白云石化进 程无疑控制了白云石结晶程度与连续分布的规模, 但埋藏白云石化作用的发生同样具有组构选择性, 即在台缘和台内的高能沉积相带, 埋藏白云石化作 用既容易发生又比较充分, 这可能与埋藏流体的运 动主要集中在沉积期或沉积期后不久建立起来的高 孔隙度-渗透率带有关(Moore, 2001; Amthor 等, 1993). 露头和井下样品观察研究发现, 塔里木盆地的埋藏
白云石化作用主要发育于台缘和台内滩相颗粒灰岩 中(图 8). 在镜下可见不同粒级结晶白云岩普遍存在 残留颗粒结构(图 9(a)), 便是埋藏白云石化作用选择 性发生的佐证。

储集空间以晶间孔和晶间溶孔为主，少量溶蚀 孔洞及裂缝. 晶间孔可以是白云石晶体间灰泥溶蚀 形成的, 也可以是继承性孔隙经埋藏白云石化后的 再调整, 部分可能来自埋藏白云石化作用. 晶间溶孔 是埋藏岩溶作用的产物, 是白云石晶体非组构选择 性溶解导致晶间孔的溶蚀扩大. 大多数的埋藏白云 岩储层均受构造裂缝作用及热液作用的叠加改造形 成少量的溶蚀孔洞及裂缝.

塔里木盆地上寒武统-鹰山组埋藏白云岩非常发 


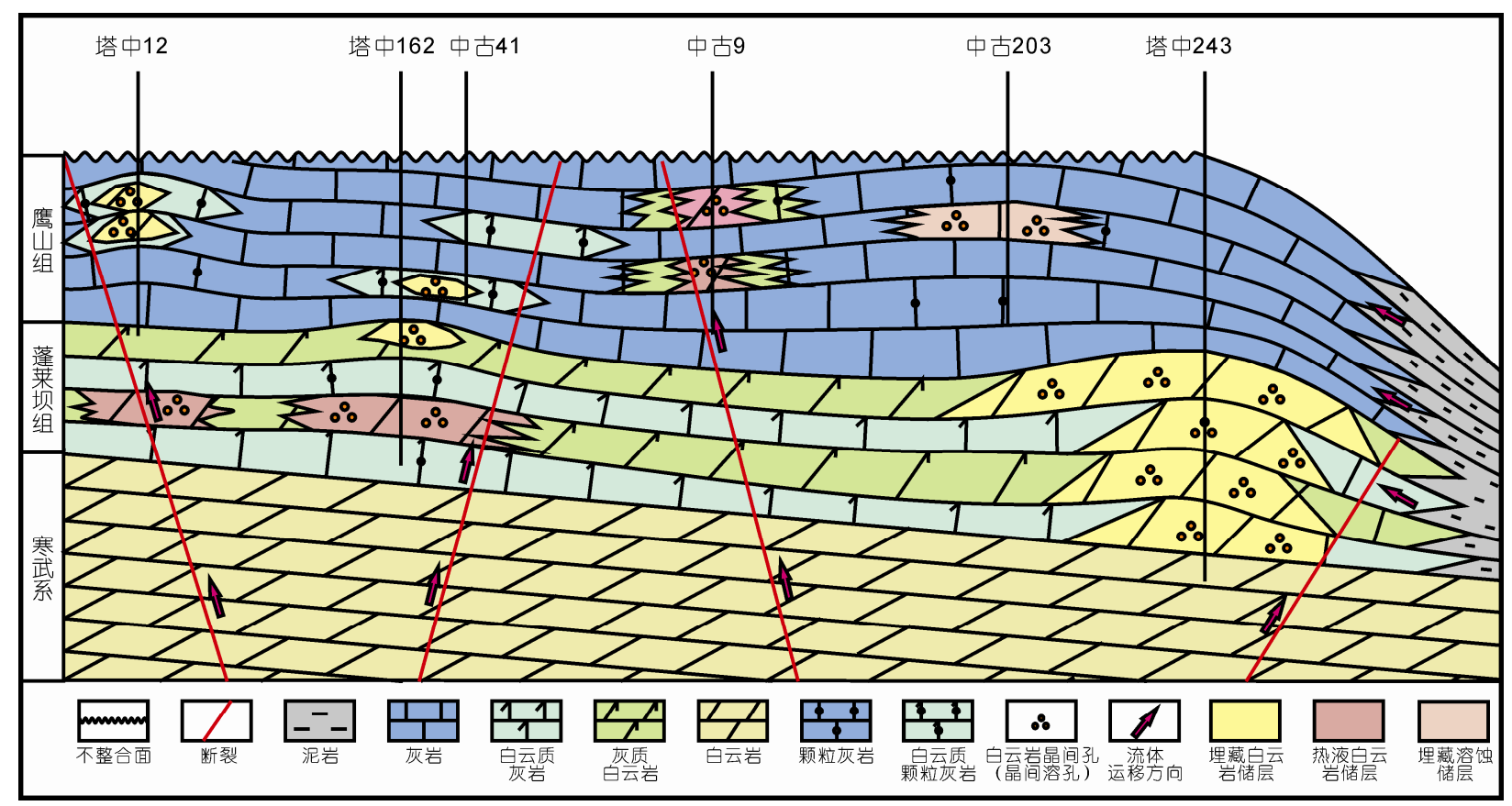

图 8 塔里木盆地塔中地区埋藏白云岩储集层和热液白云岩储集层发育模式图

原岩为台内或台缘多孔礁滩相灰岩时, 易于发生埋藏白云石化形成有效白云岩储层. 据赵文智(2011)

育, 厚数百米, 但并不是所有的埋藏白云岩都是有效 储层，大多数埋藏白云岩都是致密的. 为搞清埋藏白 云岩储层的分布规律，我们对塔里木盆地巴楚地区 永安坝下奥陶统蓬莱坝组埋藏白云岩开展了精细的 储层建模工作(图 10), 发现有效储层具以下的分布规 律: 1) 中、粗晶白云岩呈透镜状分布于粉细晶白云岩 中, 残余结构揭示原岩为颗粒灰岩；2）晶间孔主要 发育在细-中, 粗-中晶白云岩中, 孔隙度为 $3 \%$ 12\%, 渗透率 0.1 10 md, 粉细晶白云岩物性总体较差; 3) 多孔白云岩储层主要发育于四级或五级旋回向上变 浅序列的上部. 这说明了以下 3 个问题: 1) 多孔的滩 相沉积物为埋藏白云化介质提供了通道, 而且邻近 层序界面的滩相沉积物因暴露和大气淡水淋溶容易 导致滩相沉积物多孔；2）埋藏白云岩储层中的晶间 孔是继承早期孔隙并经埋藏白云石化后的再调整, 同时为有机酸、盆地热卤水及热液提供了通道, 为晶 间溶孔和溶蚀孔洞的发育奠定了基础；3）不同晶粒 白云岩侧向上的交替可能代表了原岩(石灰岩)相带 的变化, 垂向上的交替则可能代表了原岩(石灰岩)沉 积旋回的变化。

埋藏白云岩广泛发育于塔里木盆地上寒武统及
下奥陶统蓬莱坝组(图 1(d)), 四川盆地龙王庙组、黄 龙组、长兴组和鄂尔多斯盆地马家沟组四段. 岩性以 晶粒白云岩为主, 包括细晶白云岩、中晶白云岩、粗 晶白云岩等, 可残留部分原岩结构. 残留颗粒结构的 细晶、中晶及粗晶白云岩，原岩可能是颗粒灰岩，也 可能是颗粒白云岩在埋藏成岩环境重结晶使晶粒变 粗变大的产物. 原岩结构越粗, 埋藏白云石化作用时 间越长、埋藏深度越大，白云岩的晶粒往往越粗. 储 层发育的主控因素为：1）埋藏白云石化作用是埋藏 白云岩储层发育的基础, 渗透性好的碳酸盐岩为埋 藏成岩介质提供了通道；2）少量晶间孔可能形成于 埋藏白云石化作用, 但主体是对原岩孔隙的继承和 调整; 3) 埋藏溶蚀作用形成的晶间溶孔、溶洞是对埋 藏白云岩储层储集空间的重要补充，包括有机酸、盆 地热卤水及热液对白云石晶体的非组构选择性溶蚀 (Cai 等, 2008).

\section{4 热液白云岩储层}

热液白云岩是指由来自地壳深部的热液交代碳 酸盐岩(或重结晶)或沿热液通道的热液白云石晶体 析出所形成的白云岩, 鞍状白云石常见. 规模分布的 

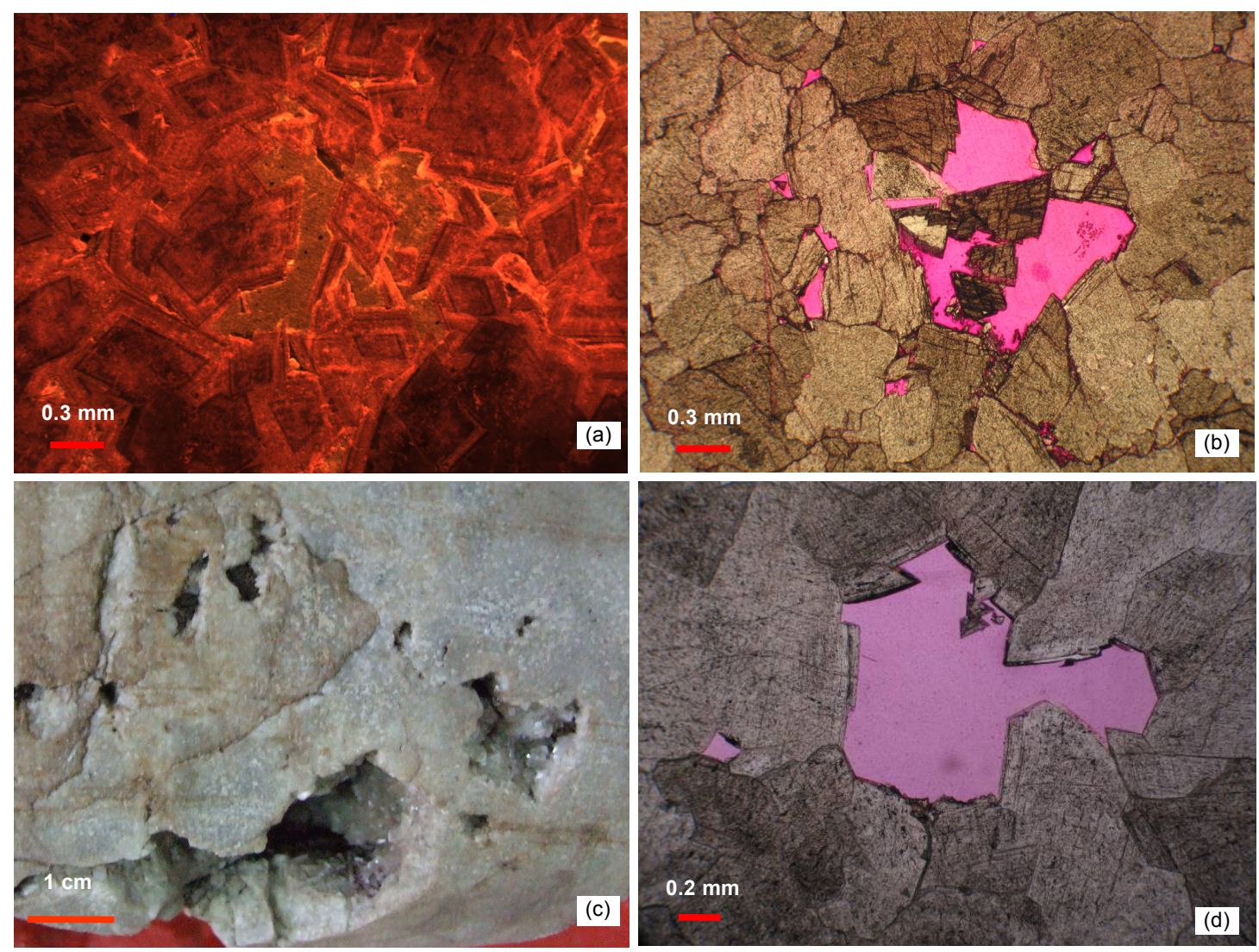

图 9 埋藏白云岩储层和热液白云岩储层显微特征

(a) 中晶白云岩, 残留原岩颗粒结构, 白云石自形晶, 见两期, 一期发中暗桔红色光, 另一期发中等桔红色光, 具环带状构造, 晶间充填亮晶 方解石发中等亮桔黄色光, 阴极发光, 中下奥陶统鹰山组, 塔里木盆地塔西南地区, 玛 2 井, $2317.60 \mathrm{~m}$; (b) 中粗晶白云岩, 白云石多为它形, 埋藏白云石化作用的产物, 同时叠加热液作用的改造, 晶间孔及晶间溶孔发育, 铸体片, 单偏光, 上寒武统, 塔里木盆地塔东地区, 米兰 1 井, $5524.50 \mathrm{~m}$; (c) 浅灰色细晶白云岩, 沿裂缝发育的溶蚀孔洞 $(>5 \mathrm{~cm})$ 为亮晶方解石充填, 与热液作用有关, 岩芯, 下奥陶统蓬莱坝组, 塔里木 盆地东河塘地区, 东河 25 井, 3-10/13; (d) 充填热液溶蚀洞穴的鞍状白云石, 具弧形边缘, 鞍状白云石晶间孔发育, 铸体片, 单偏光, 中下寒 武统, 塔里木盆地塔中-巴楚地区, 和 4 井, $4477.55 \mathrm{~m}$

热液白云岩并不多见, 这主要是深部热液往往需要 沿深大断裂或大型不整合面向上侵入，在热液通道 附近沉淀，导致热液白云岩分布的局限性.

塔里木盆地构造-热液活动比较活跃，并具多期 次的特点, 主要活动期与二叠纪全盆地广泛发育的 岩浆活动有关，因而在下古生界多个碳酸盐岩层系 发生热液交代白云石化、热液白云石的沉淀和热液溶 蚀孔洞的发育, 尤以塔中下奥陶统鹰山组最为典型, 大量的热液白云岩及热液溶蚀孔洞沿断裂及不整合 面发育.

塔里木盆地塔中地区中下奥陶统鹰山组和上奥 陶统良里塔格组之间发育不整合面，二者间存在 11 $\mathrm{Ma}$ 的地层缺失. 在巴楚隆起区, 二者间缺失地层更
多，不整合面更明显。塔中地区，鹰山组和良里塔格 组之间见层间岩溶储层段发育, 并在部分井见准层 状白云岩或斑块状白云岩. 巴楚隆起区从露头到井 下都普遍见到溶蚀型和层型或斑块状白云岩, 规模 更大. 这两个地区鹰山组和良里塔格组发育的溶蚀 型、准层状和斑块状白云岩具有以下特征: 1) 溶洞既 可以出现在不整合面之下也可以出现在不整合面之 上, 而且距离不整合面有远也有近, 分布并不规则. 如塔中 ZG41, TZ3, TZ162, TZ80 和 TZ12 井和巴楚地 区康 2 井等, 在不整合面之下见溶蚀洞穴和白云岩, 而在 TZ45 井则在不整合面之上见溶蚀型洞穴和白云 岩，说明溶蚀现象不完全由表生淋滤作用引起；2) 不整合面之下的溶洞多有充填，呈全充填或半充填 


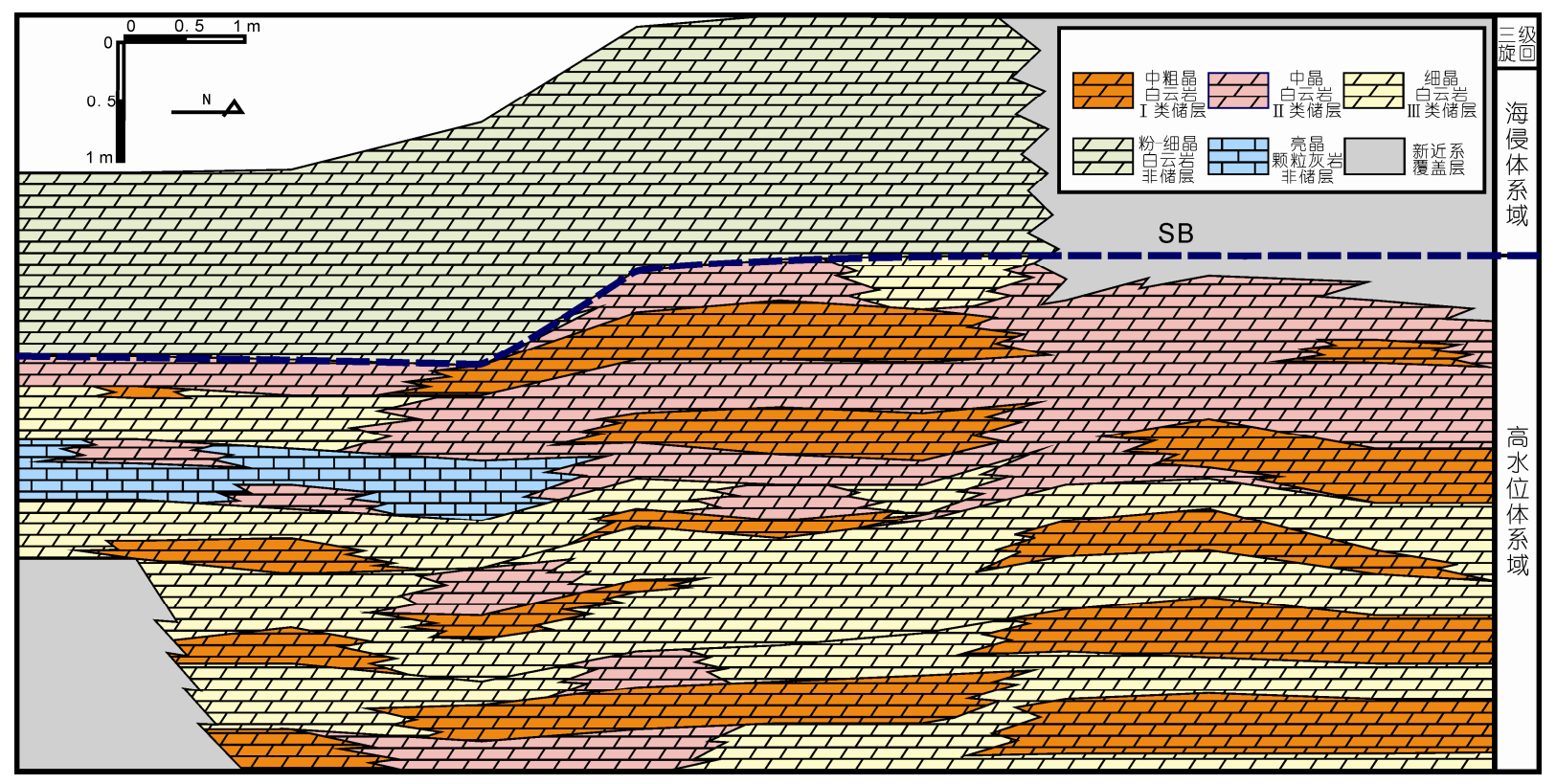

图 10 巴楚地区永安坝下奥陶统蓬莱坝组埋藏白云岩储层空间结构模型

揭示原岩(石灰岩)特征可能是白云石化过程中影响孔隙变化的重要因素

不等(如 ZG41, TZ80, 12 井), 充填物多为热液成因的 萤石、巨亮晶方解石等, 揭示溶蚀作用是热液成因的; 3) 沿不整合所见白云石化作用, 较弱时表现为灰岩 包裹斑块状白云岩, 较强时又呈残留灰岩被白云岩 包裹状, 说明这些白云岩是热液交代成因的；4）沿 深大断裂分布, 且溶洞的分布并非象表生溶蚀作用 形成者多分布在距不整合面 0 50 m 深度范围，与深 度关系不大, 特别在深大断裂处, 溶洞的分布下限无 终止深度, 说明这类洞穴的热液成因.

塔里木盆地热液沿深大断裂侵入发生溶蚀和交 代白云石化的特征, 决定这类白云岩储层的预测应 该关注以下两点：一是分布不受埋藏深度限制，且有 可能在某些大断裂部位, 越往深处去, 溶洞的发育规 模越大和连通性越好, 使得这类白云岩储层的分布 可以通过基底断裂和基底断裂与不整合面连通关系 研究进行有效预测; 二是不整合面上下及断裂的周 缘都有溶洞发育的可能性, 且越远离不整合面及裂 缝, 热液白云石化作用及热液溶蚀作用越弱.

塔里木盆地上寒武统-下奥陶统蓬莱坝组、四川 盆地古生界(龙王庙组、洗象池组、黄龙组、长兴组) 和中生界(飞仙关组)、鄂尔多斯盆地马家沟组四段埋 藏白云岩往往叠加热液白云石化作用的改造(图 8).
热液白云石化作用可以形成部分晶间孔(图 9(b)), 热 液溶蚀作用可以形成孔洞(图 9(c)), 但热液白云石及 其他热液矿物的沉淀也可充填孔隙(图 9(d)).

\section{3 白云岩储层孔隙成因研究的意义}

上述案例揭示，白云岩储集空间的形成不完全 是白云石化作用的产物. 白云石化作用总是能导致 白云岩的形成，而白云岩储集空间的形成则主要与 原岩(石灰岩)特征和各种溶蚀作用有关. 白云石化作 用形成孔隙是有严格条件限制的，如 $\mathrm{Ca}^{2+}$ 和 $\mathrm{CO}_{3}{ }^{2-}$ 来 源局限的成岩环境, 而白云石的沉淀和胶结作用恰 恰是破坏孔隙的. 塔里木、四川和鄂尔多斯盆地白云 岩储层储集空间的形成主要与原岩(石灰岩)特征和 溶蚀作用有关, 白云石化对孔隙的建造作用是次要 的(表 3), 但对孔隙的保存有一定的贡献. 由于在表 生环境白云岩比灰岩难溶蚀, 白云石构成了支撑孔 隙的格架, 同时, 减少了 $\mathrm{Ca}^{2+}$ 和 $\mathrm{CO}_{3}{ }^{2-}$ 的供给和胶结 物沉淀的潜力.

白云岩储层孔隙成因研究对储层预测具重要的 指导意义(表 4), 由于白云岩储层的储集空间并不是 白云石化作用形成的，而是受控于原岩(石灰岩)特征 
表 3 塔里木、四川和鄂尔多斯盆地白云岩储层孔隙建造和保存机理

\begin{tabular}{|c|c|c|c|c|c|c|}
\hline \multirow{2}{*}{ 序号 } & \multirow{2}{*}{ 白云岩储层类型 } & \multicolumn{2}{|c|}{ 物质基础及成因 } & \multicolumn{2}{|c|}{ 储集空间类型及成因 } & \multirow{2}{*}{$\begin{array}{l}\text { 孔隙保 } \\
\text { 存机理 }\end{array}$} \\
\hline & & 物质基础 & 成因 & 储集空间类型 & 成因 & \\
\hline 1 & $\begin{array}{l}\text { 蒸发潮坪白云岩 } \\
\text { 储层 }\end{array}$ & $\begin{array}{l}\text { 含亳泥粉晶云岩, } \\
\text { 石膏呈斑块状、结核 } \\
\text { 状分布 }\end{array}$ & $\begin{array}{l}\text { 干旱气候条件 } \\
\text { 下的蒸发潮坪 } \\
\text { 环境 }\end{array}$ & $\begin{array}{l}\text { 稁模孔为主, 少 } \\
\text { 量晶间孔及裂缝 }\end{array}$ & $\begin{array}{l}\text { 表生期大气淡水对石膏及未 } \\
\text { 云化灰质的溶蚀 }\end{array}$ & \multirow{4}{*}{$\begin{array}{l}\mathrm{Ca}^{2+} \text { 和 } \mathrm{CO}_{3}{ }^{2-} \\
\text { 来源局限的 } \\
\text { 成岩环境导 } \\
\text { 致胶结物缺 } \\
\text { 失; 不易溶 } \\
\text { 的白云石构 } \\
\text { 成孔隙支撑 } \\
\text { 格架 }\end{array}$} \\
\hline 2 & $\begin{array}{l}\text { 蒸发台地白云岩 } \\
\text { 储层 }\end{array}$ & $\begin{array}{l}\text { 含文石或高镁方解 } \\
\text { 石的颗粒白云岩及 } \\
\text { 礁(丘)白云岩, 粒间 } \\
\text { 和格架孔可以充填 } \\
\text { 石膏 }\end{array}$ & $\begin{array}{l}\text { 干旱气候条件 } \\
\text { 下的蒸发台地 } \\
\text { (盐湖)环境 }\end{array}$ & $\begin{array}{l}\text { 颗粒铸模孔, 残 } \\
\text { 留粒间孔和格架 } \\
\text { 孔, 石膏溶孔 }\end{array}$ & $\begin{array}{l}\text { 表生期大气淡水对石膏及未 } \\
\text { 云化文石或高镁方解石颗粒 } \\
\text { 的溶蚀 }\end{array}$ & \\
\hline 3 & 埋藏白云岩储层 & $\begin{array}{l}\text { 多孔的碳酸盐沉积, } \\
\text { 以多孔的礁滩相沉 } \\
\text { 积为主 }\end{array}$ & $\begin{array}{l}\text { 台内和台缘礁 } \\
\text { 滩相沉积; 原 } \\
\text { 生孔隙或表生 } \\
\text { 期次生溶孔 }\end{array}$ & $\begin{array}{l}\text { 残留粒间孔或格 } \\
\text { 架孔, 晶间孔和 } \\
\text { 晶间溶孔 }\end{array}$ & $\begin{array}{l}\text { 少量晶间孔可能形成于埋藏 } \\
\text { 白云石化作用, 但主体是对 } \\
\text { 原岩孔隙的继承和调整, 晶 } \\
\text { 间溶孔形成于埋藏溶蚀作用 }\end{array}$ & \\
\hline 4 & 热液白云岩储层 & $\begin{array}{l}\text { 沿断裂及不整合面 } \\
\text { 分布的多孔碳酸盐 } \\
\text { 岩 }\end{array}$ & $\begin{array}{l}\text { 沉积和成岩综 } \\
\text { 合作用的产物 }\end{array}$ & $\begin{array}{l}\text { 晶间孔和晶间溶 } \\
\text { 孔, 热液溶蚀孔 } \\
\text { 洞 }\end{array}$ & $\begin{array}{l}\text { 晶间孔可能形成于热液白云 } \\
\text { 石化作用或是对原岩孔隙的 } \\
\text { 继承和调整, 晶间溶孔和溶 } \\
\text { 洞形成于热液溶蚀作用 }\end{array}$ & \\
\hline
\end{tabular}

表 4 塔里木、四川和鄂尔多斯盆地白云岩储层分布规律

\begin{tabular}{|c|c|c|c|}
\hline 序号 & 白云岩储层类型 & 侧向分布规律 & 垂向分布规律 \\
\hline 1 & 蒸发潮坪白云岩储层 & $\begin{array}{l}\text { 干旱气候条件下的蒸发潮坪膏云岩, 带状或 } \\
\text { 准层状分布, 受相带控制 }\end{array}$ & $\begin{array}{l}\text { 向上变浅旋回顶部的层序界面(同生期暴露面)之下数 } \\
\text { 米厚的稁云岩, 多个向上变浅的蒸发潮坪旋回可导致 } \\
\text { 储层垂向上多套叠置 }\end{array}$ \\
\hline 2 & 蒸发台地白云岩储层 & $\begin{array}{l}\text { 干旱气候条件下蒸发台地(盐湖)周缘及亳盐 } \\
\text { 层之下的礁滩相白云岩、亳云岩, 环带状及 } \\
\text { 层状分布, 受相带控制 }\end{array}$ & $\begin{array}{l}\text { 向上变浅旋回顶部的层序界面(同生期暴露面)之下数 } \\
\text { 米厚的礁滩相白云岩、亳云岩, 多个向上变浅旋回可 } \\
\text { 导致储层垂向上多套叠置 }\end{array}$ \\
\hline 3 & 埋藏白云岩储层 & $\begin{array}{l}\text { 不同晶粒白云岩侧向上的交替可能代表了原 } \\
\text { 岩(石灰岩)相带的变化, 受相带控制, 主要 } \\
\text { 发育于台缘或台内白云石化(交代或重结晶) } \\
\text { 的多孔礁滩相沉积中 }\end{array}$ & $\begin{array}{l}\text { 不同晶粒白云岩垂向上的交替则可能代表了原岩(石 } \\
\text { 灰岩)沉积旋回的变化, 原岩的多孔性主要与同生期 } \\
\text { 淡水溶蚀作用有关, 有效储层分布于向上变浅旋回顶 } \\
\text { 部的层序界面(同生期暴露面)之下的晶粒白云岩, 多 } \\
\text { 个向上变浅旋回可导致储层垂向上多套叠置 }\end{array}$ \\
\hline 4 & 热液白云岩储层 & \multicolumn{2}{|c|}{$\begin{array}{l}\text { 沿断裂、不整合面等热液通道呈准层状、透镜状分布; 由热液通道向周缘, 热液白云石化作用逐渐减 } \\
\text { 弱; 同期热液活动可以穿越多个层系, 多期热液活动可以相互叠置 }\end{array}$} \\
\hline
\end{tabular}

和各种溶蚀作用, 故预测白云岩与预测白云岩储层 是两个截然不同的问题.

塔里木、四川和鄂尔多斯盆地不同地质历史时期 蒸发潮坪白云岩的分布面积可以很广, 连续厚度也 可以很大. 由于孔隙的发育主要是膏云岩在表生期 受大气淡水淋溶使石膏溶蚀形成膏模孔的产物, 并 不是白云石化作用的产物, 导致蒸发潮坪白云岩储 层的分布范围远不如蒸发潮坪白云岩广, 但有规律 可循. 干旱气候条件下的石膏沉淀是储层发育的必 要条件, 蒸发潮坪相带含石膏结核的白云岩是储层
发育的物质基础，两者控制储层的侧向分布; 向上变 浅旋回顶部(或层序界面之下)膏云岩的暴露和受大 气淡水淋溶是储层发育的关键，并控制储层的垂向 分布, 多个向上变浅的蒸发潮坪旋回可导致储层垂 向上多套叠置.

同理，由于蒸发台地白云岩储层孔隙的发育主 要是表生期大气淡水对石膏及未云化文石或高镁方 解石颗粒溶蚀的产物, 并不是白云石化作用的产物, 导致塔里木、四川和鄂尔多斯盆地蒸发台地白云岩储 层的分布范围远不如蒸发台地白云岩广，但有规律 
可循. 干旱气候条件下蒸发台地(盐湖)渗透回流白云 石化是储层发育的必要条件, 含未云化的文石、高镁 方解石颗粒及云化过程中沉淀的石膏等可溶性矿物 的礁滩白云岩是储层发育的物质基础, 含可溶性矿 物的礁滩白云岩暴露和受大气淡水淋溶是储层发育 的关键，侧向上储层分布于蒸发台地(盐湖)周缘及膏 盐层或盐岩层之下呈环带状及层状分布, 垂向上储 层分布于向上变浅旋回顶部(层序界面之下)数米厚 的礁滩相白云岩、膏云岩中, 多个向上变浅旋回可导 致储层垂向上多套叠置.

埋藏白云岩储层在塔里木、四川及鄂尔多斯盆地 广泛发育, 由于储层的孔隙主要是对原岩(石灰岩)孔 隙的继承和调整, 不是白云石化作用的产物, 而且原 岩(石灰岩)孔隙主要与同生期淡水溶蚀作用有关, 导 致埋藏白云岩储层具有很大的相控和层序界面控制 的背景. 层序界面之下的礁滩相沉积往往具有较高 的初始孔隙度(残留原生孔隙和淡水溶蚀形成的次生 孔隙)和抗压实能力(早期胶结构成抗压实格架), 经 历白云石化后易于形成多孔的埋藏白云岩储层. 不
同晶粒白云岩侧向上的交替可能代表了原岩(石灰岩) 相带的变化, 垂向上的交替则可能代表了原岩(石灰 岩)沉积旋回的变化, 这为原岩结构难以恢复的晶粒 白云岩相带和旋回分析提供了理论依据. 储层侧向 上分布于台缘或台内白云石化(交代或重结晶)的多 孔礁滩相沉积中, 垂向上分布于向上变浅旋回顶部 (层序界面之下) 的晶粒白云岩中, 多个向上变浅旋回 可导致储层垂向上多套叠置.

构造-热液作用以形成热液溶蚀孔洞为主, 并 部分为热液矿物充填, 鞍状白云石的沉淀肯定是 破坏孔隙的. 热液白云石化作用对晶间孔的发育 可能有一定的贡献, 但也严格限定在 $\mathrm{Ca}^{2+}$ 和 $\mathrm{CO}_{3}{ }^{2-}$ 来 源局限的成岩环境. 热液白云岩中发育的晶间孔主 要是对原岩孔隙的继承和调整, 部分来自埋藏溶蚀 作用. 热液白云岩储层沿断裂、不整合面及渗透 性好的岩层等热液通道呈准层状、透镜状分布. 由热 液通道向周缘, 热液白云石化作用逐渐减弱. 同期热 液活动可以穿越多个层系, 多期热液活动可以相互 叠置.

致谢感谢塔里木油田分公司勘探开发研究院潘文庆教授、长庆油气田分公司勘探开发研究院包洪平高工及西南油 气田分公司勘探开发研究院洪海涛高工在论文撰写过程中提供了大量的资料、给予了宝贵的意见和建议; 感 谢杭州地质研究院的潘立银和张杰, 他们在论文的英文版插图翻译及全文校稿过程中提供了很多的帮助.

\section{参考文献}

白国平. 2006. 世界碳酸盐岩大油气田分布特征. 岩相古地理, $8: 241-250$

范明, 蒋小琼, 刘伟新, 等. 2007. 不同温压条件下 $\mathrm{CO}_{2}$ 水溶液对碳酸盐岩的溶蚀作用. 沉积学报, 25: 825-830

方少仙, 侯方浩, 董兆雄. 2003. 上震旦统灯影组中非叠层生态系蓝细菌白云岩. 沉积学报, 21: 96-105

何江, 方少仙, 侯方浩, 等. 2009. 鄂尔多斯盆地中部气田中奥陶统马家沟组岩溶型储层特征. 石油与天然气地质, 30: 350-356

黄先平, 杨雨. 2003. 川东北部地区下三叠统飞仙关组鲕滩储层发育控制因素及地质分布规律. 海相油气地质, 8: 89-97

雷市军, 强子同. 1994. 川东及邻区上二叠统生物礁的白云岩化. 地质论评, 40: 534-543

乔琳, 沈昭国, 方少仙, 等. 2007. 鄂尔多斯盆地靖边潜台及其周边地区中奥陶统马家沟组马五 1 4 亚段储层非均质性主要控制因素. 海相

油气地质, 12: 12-20

沈安江, 周进高, 辛勇光, 等. 2008. 四川盆地雷口坡组白云岩储层类型及成因. 海相油气地质, 13: 19-28

施泽进, 彭俊, 王勇. 2010. 川东南地区灯影组储层特征及其控制因素研究. 成都理工大学学报(自然科学版), 37: 1-8

王一刚, 文应初. 1996. 川东石炭系碳酸盐岩储层孔隙演化中的古岩溶和埋藏溶解作用. 天然气工业, 16: 18-23

赵文智, 沈安江, 胡素云, 等. 2011. 中国碳酸盐岩储集层大型化发育的地质条件与分布特征. 石油勘探与开发, 39: 1-12

赵文智, 沈安江, 胡素云, 等. 2012. 塔里木盆地寒武-奥陶系白云岩储层类型与分布特征. 岩石学报, 28: 758-768

郑剑锋, 沈安江, 莫妮亚, 等. 2010. 塔里木盆地寒武系-下奥陶统白云岩成因及识别特征. 海相油气地质, 15: 6-14

Adams J E, Rhodes M L. 1961. Dolomitization by seepage refluxion. AAPG Bull, 44: 1921-1920

Amthor J E, Mountjoy E W, Machel H G. 1993. Subsurface dolomites in upper Devonian Leduc formation buildups, central part of Rimbey-Meadowbrook reef trend, Alberta, Canada. CSPG Bull, 41: 164-185

Badiozamani K. 1973. The Dorag dolomitization model-application to the Middle Ordovician of Wisconsin. J Sed Petrol, 43: 965-984

1938 
Beach D K. 1982. Depositional and diagenetic history of Pliocene-Pleistocene carbonates of northwestern Great Bahama Bank: Evolution of a carbonate platform. Doctoral Dissertation. Miami: University of Miami. 425

Bush P R. 1973. Some aspects of the diagenetic history of the sabkha in Abu Dhabi, Persian Gulf. New York: Springer-Verlag. 395-407

Cai C F, Li K K, Li H T, et al. 2008. Evidence for cross formational hot brine flow from integrated Sr/Sr, REE and fluid inclusions of the Ordovician veins in central Tarim. Appl Geochem, 23: 2226-2235

Fairbridge R W. 1957. Regional aspects of carbonate deposition. SEPM Spec Publ, 5: 124-178

Graham R D, Langhorne B, Smith Jr. 2006. Structurally controlled hydrothermal dolomite reservoir facies: An overview. AAPG Bull, 90: 1641-1690

Hardie L A. 1987. Dolomitization: A critical view of some current views. J Sed Petrol, 57: 166-183

Lucia F J, Major R P. 1994. Porosity evolution through hypersaline reflux dolomitization. IAS Spec Publ, 21: 325-341

Lucia F J. 1999. Carbonate Reservoir Characterization. Berlin Heidelberg: Springer-Verlag. 226

Marco A, Pauline N M. 2000. A natural analog for a fractured and faulted reservoir in dolostone: Triassic Sella Group, Northern Italy. AAPG Bull, 84: 314-344

Mattes B W, Mountjoy E W. 1980. Burial dolomitization of the Upper Devonian Miette buildup, Jasper National Park, Alberta. SEPM Spec Publ, 28: 259-297

Mckenzie J A, Hsu K J, Schneider J E. 1980. Movement of subsurface waters under the sabkha, Abu Dhabi, UAE, and its relation to evaporative dolostone genesis. SEPM Spec Publ, 28: 11-30

Montanez I P. 1994. Late diagenetic dolomitization of Lower Ordovician, Upper Knox Carbonates: A record of the hydrodynamic evolution of the southern Appalachian Basin. AAPG Bull, 78: 1210-1239

Moore C H. 1989. Carbonate Diagenesis and Porosity. New York: Elsevier. 338

Moore C H, Heydari E. 1993. Burial diagenesis and hydrocarbon migration in platform limestones: A conceptual model based on the Upper Jurassic of Gulf Coast of USA. AAPG Bull: 213-229

Moore C H. 2001. Carbonate Reservoirs-porosity Evolution and Diagenesis in a Sequence Stratigraphic Framework. Amsterdam-London-New York-Oxford-Paris-Shannon-Tokyo: Elsevier. 293-298

Purser B H, Brown A, Aissaoui D M. 1994. Nature, origins and evolution of porosity in dolomites. IAS Spec Publ, 21: 283-308

Vahrenkamp V C, Swart P K. 1994. Late Cenozoic dolomites of the Bahamas: Metastable analogues for the genesis of ancient platform dolomites. IAS Spec Publ, 21: 133-153

Wey1 P K. 1960. Porosity through dolomitization: Conservation-of-mass requirements. J Sed Petrol, 30: 85-90 